Bangladesh J. Zool. 49(1): 169-173, 2021

- Scientific note

ISSN: 0304-9027

eISSN: $2408-8455$

\title{
NEW DISTRIBUTIONAL RECORD OF EUPTEROTE TESTACEA (WALKER, 1855) (LEPIDOPTERA, EUPTEROTIDAE) FROM SYLHET DIVISION, BANGLADESH
}

Syeda Fahmida Jahan, Arnob Saha, Sanjida Sultana and Murshida Begum*

Department of Zoology, University of Dhaka, Dhaka, Bangladesh

Eupterote Hübner, 1820 is a genus of moth, which belongs to the subfamily Eupterotinae and is represented by some 30 to 80 species globally distributed (Nässig 2000). The genus is still poorly known, and the exact number of species remains unknown (Raha et al. 2017). In the neighboring country India, a total of 14 species of Eupterote has been recorded (Raha et al. 2017). Among these species, two inhabit Bangladesh: $E$. lineosa (Walker, 1855) and $E$. testacea (Walker, 1855) (Hampson 1892, Raha et al. 2017). The distribution of Eupterote testacea has so far been reported in northeast India, Myanmar, and Bangladesh. In Bangladesh, this species has been only recorded once almost 165 years ago by Walker in 1855 from Sylhet (Hampson 1892). As a eupterotid moth, E. testacea exhibits predominantly nocturnal flight activity (Nässig 2000). It is one of the main pests and feeds upon cardamom shoot (Aravind et al. 2017) and uses Elettaria cardamomum (Maton), Imperata cylindrical (Beauvois), Loropetalum chinense (Oliver), Nephelium lappaceum (Linneaus), Saccharum officinarum (Linneaus), Sorghum (Moench), and Typhonium roxburghii (Schott) as its host plant (Robinson et al. 2010).

Only one literature record (Walker 1855) of Eupterote testacea from Bangladesh indicates that the distribution of this species remains poorly known in this country. To help fill this gap of its distribution and morphometric data, we provide a new locality record, an updated distributional map, and morphometric data of E. testacea from this country.

During a field visit on 26 August 2020 in Habiganj district $\left(24.2546^{\circ} \mathrm{N}\right.$, $91.3760^{\circ} \mathrm{E}$ ), a total of six individuals were observed. We determined the sexes through careful observation by detecting the genitalia after collection. Specimens were collected by hand and placed directly in $70 \%$ ethanol for preservation. The identification of these specimens was later confirmed by following the description of this specimen based on (Hampson 1892). Photographs of the specimen were taken using a Nikon D5300 DSLR with a 55-200 mm VR lens and the photographic vouchers were deposited to Professor Md. Kazi Zaker

*Author for correspondence: <murshida1972@yahoo.com>

(C)2021 Zoological Society of Bangladesh DOI: https://doi.org/10.3329/bjz.v49i1.53692 
Table 1. Morphometric data of 6 collected individuals of $E$. testacea. Body parts that differed significantly from male moths to female moths are indicated by asterisks (*)

\begin{tabular}{lccc}
\hline \multirow{1}{*}{ Body parts } & $\begin{array}{c}\text { Male E. testacea } \\
\text { Moth }\end{array}$ & $\begin{array}{c}\text { Female E. testacea } \\
\text { Moth }\end{array}$ & P-value \\
\cline { 2 - 3 } & (Mean $\pm \mathrm{SD}) \mathrm{mm}$ & (Mean $\pm \mathrm{SD}) \mathrm{mm}$ & \\
\hline Antenna Length* & $9.67 \pm 0.58$ & $6.00 \pm 1.00$ & $<0.05$ \\
Eye Distance & $3.00 \pm 0.00$ & $3.00 \pm 0.00$ & $>0.05$ \\
Fore wing Length* & $15.00 \pm 0.00$ & $11.00 \pm 0.00$ & $<0.05$ \\
Fore wing Width* & $29.67 \pm 2.08$ & $36.00 \pm 1.73$ & $<0.05$ \\
Hind wing Length & $17.00 \pm 0.00$ & $18.67 \pm 1.52$ & $>0.05$ \\
Hind wing Width & $18.00 \pm 1.73$ & $16.67 \pm 1.15$ & $>0.05$ \\
Wingspan* & $59.33 \pm 4.16$ & $72.00 \pm 3.46$ & $<0.05$ \\
Foreleg Length* & $7.00 \pm 1.00$ & $6.33 \pm 0.58$ & $<0.05$ \\
Midleg Length & $11.00 \pm 1.00$ & $11.67 \pm 0.58$ & $>0.05$ \\
Hindleg Length & $9.33 \pm 0.58$ & $10.63 \pm 0.55$ & $>0.05$ \\
\hline
\end{tabular}
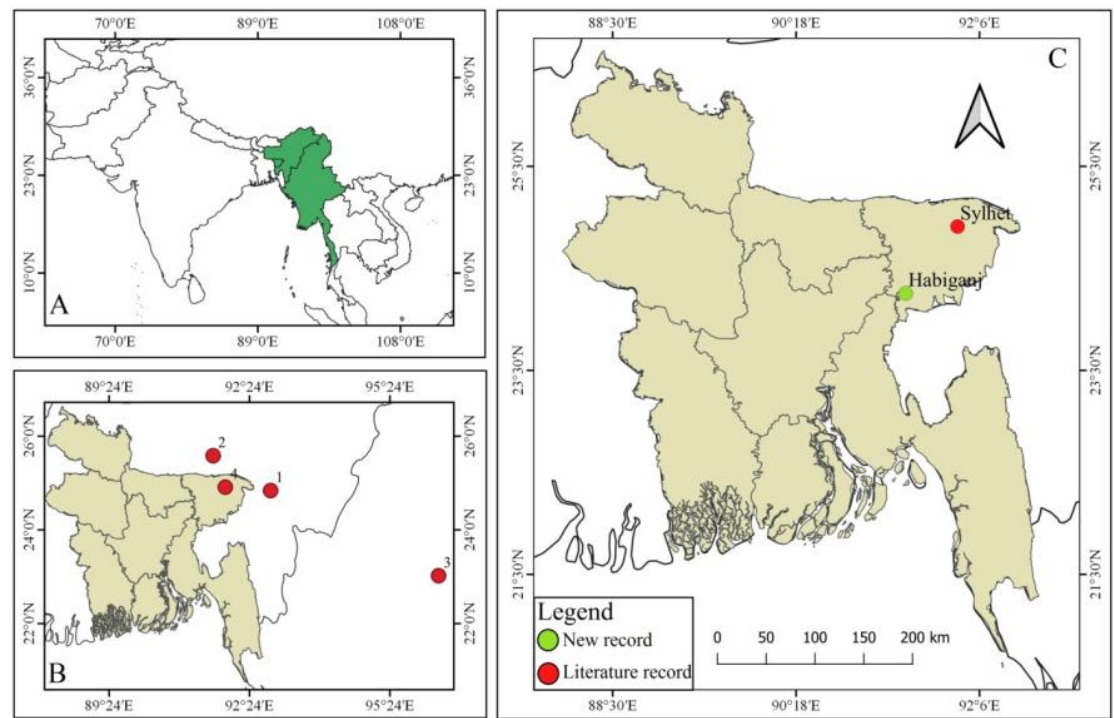

Fig. 1.A. Map showing the global range of Eupterote testacea (dark green) according to (Raha et al. 2017). B. Map showing previous literature records of Eupterote testacea in world. The previous localities are marked by red rectangles and numbered: $1=$ Cachar district, Assam; $2=$ Khasi hills, Meghalaya; 3 = Bernardmyo, Myanmar; 4 = Sylhet, Bangladesh. C. Map showing the distribution of Eupterote testacea in Bangladesh. Previous record from Sylhet is shown by the red circle and the new record from Habiganj district is marked with the light green circle.

Husain Museum, Department of Zoology, University of Dhaka, Bangladesh (Voucher ID No. W35001, W35002, W35003, W35004, W35005, W35006). Morphometric comparisons were performed by comparing the measurements of the body parts. Measurements of the body parts were done using the vernier scale. A paired t-test was done to compare the morphometric data of males and females specimens. The collected specimens matched the morphological description reported for the species by Walker (1855) having fulvous yellow 


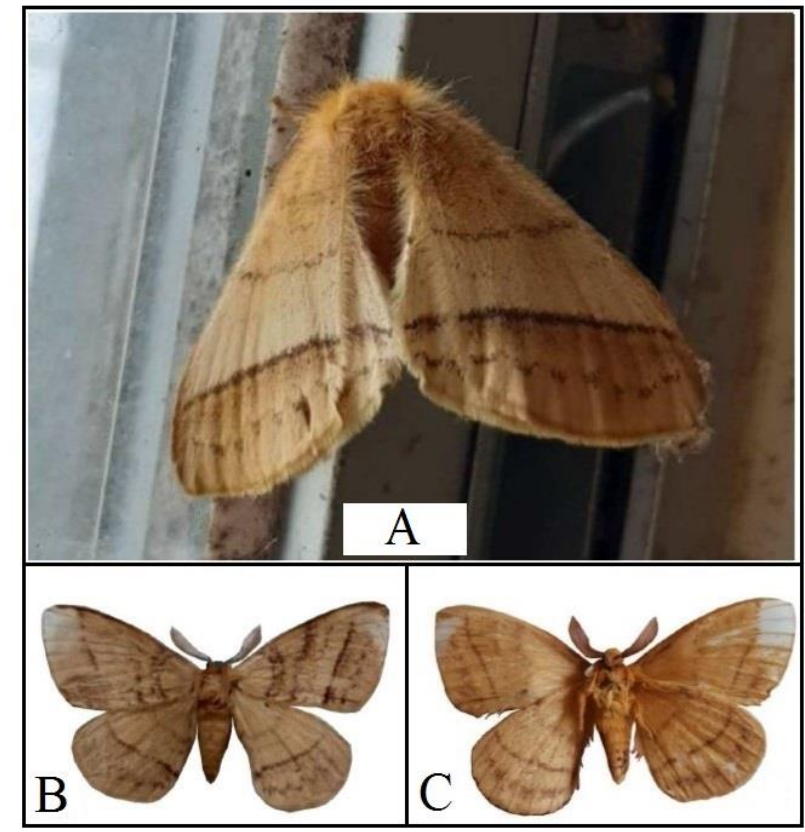

Fig. 2. Eupterote testacea (Walker, 1855) A. Habitus female. B. Dorsal view of male. C. Ventral view of male. (Show different lines on the photographs of the wings as described in your findings by using arrows and scale bars).

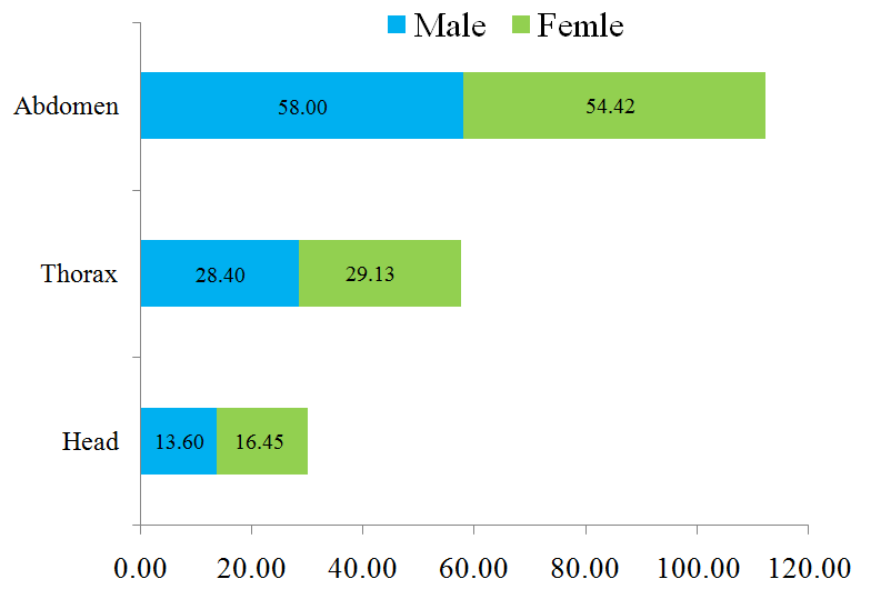

Fig. 3. Comparison of the percent of body parts of male and female individuals.

head and thorax, abdomen and wings pale ochreous yellow, forewing crossed by two ante medial and two medial, nearly straight indistinct dark lines, a double postmedial similar line, a waved submarginal line and hind wing with an antemedial line and a double postmedial line (Fig. 2). 
Morphometric data showed a significant difference in "Antenna length", "Forewing length", "Forewing width", "Wingspan", and "Foreleg length" between male and female individuals of E. testacea. Total wingspan varied the most; in male wingspan varied from $58 \mathrm{~mm}$ to $64 \mathrm{~mm}(59.33 \pm 4.167 \mathrm{~mm})$, wherein female, wingspan varied from $70 \mathrm{~mm}$ to $76 \mathrm{~mm}(72 \pm 3.46 \mathrm{~mm})$. The data for antennae, distance in between the two compound eye, total wingspan, forewing length and width, and hindwing length and width, and legs lengths are given in Table 1. Present results were not in agreement with the results observed by Hampson (1892) where a longer wingspan was observed. In the current study body parts ratio (e.g., Head, Thorax, and Abdomen) indicated that the ratio of the head, thorax, and abdomen was more or less the same for males and females of $E$. testacea species (Fig. 3).

Since its discovery in 1855 from the Sylhet division (Walker 1855), E. testacea has been recorded only a few times worldwide and no sightings have occurred over the last 165 years after its discovery here in Bangladesh. Hampson (1892) reported E. testacea from Cachar district, Assam; Khasi hills, Meghalaya; Bernardmya, Myanmar; and Sylhet, Bangladesh. Our new observation record from Habiganj district, Sylhet matches its previous known geographical range and extends its distribution about $92 \mathrm{~km}$ southwest. Imperata cylindrica, which is one of the major host plants of E. testacea was found near its observed location and suppose that it provides a suitable habitat for the species near the observed locality.

With no comprehensive studies on this genus or species available from the country except the works of Walker (1855), our new record and morphometric data might help in promoting more studies on ecology, behavior, and other aspects of E. testacea.

Acknowledgments: We thank Jahir Rayhan for confirming the species identity.

\section{LITERATURE CITED}

Aravind, J., Samiayyan, K. and Kuttalam, S. 2017. A novel insecticide diafenthiuron 50WP against cardamom shoot and capsule borer C. punctiferalisguenee. Int. J. Cur. Microbiol. Appl. Sci.6(10): 4995-5004.

Hampson, G.F. 1892. The Fauna of British India, including Ceylon and Burma. Taylor and Francis, London. 527 pp.

Hübner, J. 1820. Verzeichniss bekannter Schmettlinge. Verfasser zu Finden, Augsburg. 72 pp.

Nässig, W.A. 2000. A new and remarkable species of Eupterote from the mountains of West Sumatra (Lepidoptera: Eupterotidae). Heteroc. sumatr. 12(2): 66-77. 
Raha, A., Majumder, A., Sanyal, A.K. and Chandra, K. 2017. On three species of genus Eupterote Hübner, [1820] from Chhattisgarh, with a consolidated species list of the genus from India (Lepidoptera: Eupterotidae). SHILAP Revta. lepid.45(180): 651-664.

Robinson, G.S., Ackery, P.R., Kitching, I.J., Beccaloni, G.W. and Hernández, L.M. 2010. HOSTS - A Database of the World's Lepidopteran Host plants. http://www.nhm.ac.uk/hosts. Accessed on: 2020-09-12.

Walker, F. 1855. List of the specimens of lepidopterous insects in the collection of the British Museum.Trustees of the British Museum, London. 2040 pp.

(Manuscript received on 1 October, 2020 revised on 15 January, 2021) 